\title{
PCR based mutation screening of the laminin $\alpha 2$ chain gene (LAMA2): application to prenatal diagnosis and search for founder effects in congenital muscular dystrophy
}

Pascale Guicheney, Nicolas Vignier, Xu Zhang, Yi He, Corinne Cruaud, Véronique Frey, Anne Helbling-Leclerc, Pascale Richard, Brigitte Estournet, Luciano Merlini, Haluk Topaloglu, Marina Mora, Jean-Paul Harpey, Charles-Antoine Haenggeli, Annie Barois, Bernard Hainque, Ketty Schwartz, Fernando M S Tomé, Michel Fardeau, Karl Tryggvason

\section{INSERM U153, Groupe Hospitalier Pitié-Salpêtrière, Institut de Myologie, 47 Boulevard de l'Hôpital, 75651 Paris Cedex 13, France P Guicheney \\ $N$ Vignier \\ $\mathrm{Y} \mathrm{He}$ \\ A Helbling-Leclerc \\ K Schwartz \\ F M S Tomé \\ $M$ Fardeau}

\section{Department of}

Medical Biochemistry

and Biophysics, Karolinska Institute, 17177 Stockholm,

Sweden

$X$ Zhang

K Tryggvason

Généthon, 1 Rue de l'Internationale, 91002 Evry, France

C Cruaud

Service de Biochimie, Groupe Hospitalier Pitié-Salpêtrière, 47 Boulevard de l'Hôpital, 75651 Paris Cedex 13, France V Frey

P Richard

B Hainque

\section{Service de}

Pédiatrie-Réanimation Infantile, Hôpital

Raymond-Poincaré, 92380 Garches, France B Estournet

A Barois

\section{Neuromuscular}

Laboratory, Rizzoli

Orthopaedic Institute,

Bologna, Italy

L Merlini

\section{Department of}

Paediatric Neurology,

Hacettepe Children's

Hospital, Ankara,

Turkey

H Topaloglu

\begin{abstract}
Classical congenital muscular dystrophy with merosin deficiency is caused by mutations in the laminin $\alpha 2$ chain gene (LAMA2). Extended sequencing of the introns flanking the 64 LAMA2 exons was carried out and, based on these sequences, oligonucleotide primers were designed to amplify the coding region of each exon separately. By PCR-SSCP analysis, we identified eight new mutations in nine families originating from various countries. All induced a premature truncation of the protein, either in the short arm or in the globular C-terminal domain. A 2 bp deletion in exon 13, 2098delAG, was found in three French non-consanguineous families and a nonsense mutation of exon 20, Cys $^{967}$ stop, in two other nonconsanguineous families originating from Italy. Determination of rare intragenic polymorphisms permitted us to show evidence of founder effects for these two mutations suggesting a remote degree of consanguinity between the families. Other, more frequent polymorphisms, G to A 1905 (exon 12), A to G 2848 (exon 19), $A$ to $G 5551$ (exon 37), and $G$ to $A 6286$ (exon 42), were used as intragenic markers for prenatal diagnosis. This study provides valuable methods for determining the molecular defects in LAMA2 causing merosin deficient congenital muscular dystrophy.

(F Med Genet 1998;35:211-217)
\end{abstract}

Keywords: congenital muscular dystrophy; merosin; laminin-2

Merosin deficient congenital muscular dystrophy (MD CMD) is an autosomal recessive muscle disorder with homogeneous clinical features represented by early onset of muscle hypotonia, weakness, severe contractures, and white matter changes in the central nervous system..$^{1-3}$ The children generally have normal intelligence and in a number of cases epileptic seizures. ${ }^{4}$ Muscle biopsies show marked variation in fibre size, necrotic and regenerating processes at early stages, and interstitial fibrosis. Immunohistochemical analyses have shown absence or reduction of the laminin $\alpha 2$ chain around the skeletal muscle fibres. ${ }^{5}$ Disruption of the basement membrane of muscle fibres based on electron microscopy examination has been reported in a few cases. ${ }^{67}$ Brain magnetic resonance imaging (MRI) has indicated diffuse white matter changes clearly associated not only with complete deficiency ${ }^{8-10}$ but also with partial deficiency of the laminin $\alpha 2$ chain. ${ }^{11-13}$ This typical pattern is usually detectable after 6 months of age. ${ }^{14}{ }^{15}$ Abnormal somatosensory and visual evoked potentials, as well as motor nerve conduction, have been described. ${ }^{16}{ }^{17}$ Extensive brain abnormalities, such as cortical dysplasia, have been reported in some cases. ${ }^{418}$

Several mutations causing either a partial $^{111920}$ or a complete deficiency of the laminin $\alpha 2$ chain have been identified in the laminin $\alpha 2$ chain gene. ${ }^{21-23}$ The laminins are a family of large trimeric basement membrane glycoproteins composed of $\alpha, \beta$, and $\gamma$ chains. The three subunit chains associate at their carboxyl termini in a coil, usually forming a cross shaped molecule with the long arm made up by the coil and the amino termini forming the short arms. The laminin-2 (merosin) and the laminin-4 (s-merosin) isoforms, which have molecular formulae $\alpha 2: \beta 1: \gamma 1$ and $\alpha 2: \beta 2: \gamma 1$, respectively, are characteristically enriched in basement membranes surrounding skeletal muscle fibres. ${ }^{24}$ The high tissue specificity of these isoforms is provided only by the $\alpha 2$ chain, as the other component chains of the laminin isoforms, the $\beta 1$ or $\beta 2$ and $\gamma 1$ chains, are ubiquitous. The $\alpha 2$ polypeptide chain contains 3110 residues. ${ }^{25}$ Detailed characterisation of the gene encoding this chain, LAMA2, showed that it exceeds 260000 base pairs in size and contains 64 exons. $^{26}$

In the present study, we extended the sequencing of introns flanking all exons in order to enable PCR amplification of large enough segments for thorough mutation analysis of all the 64 exon regions. Oligonucleotide primers were designed to amplify each exon, which was then studied by PCR-SSCP analysis and direct sequencing. New mutations and several polymorphisms were identified and applications for prenatal diagnosis and search for founder effects were shown. 


\section{Department of Neuromuscular \\ Diseases, Istituto \\ Nazionale Neurologico \\ "Carlo Besta", 20133 \\ Milano, Italy \\ M Mora \\ Clinique de Pédiatrie \\ et de Génétique \\ Médicale, Groupe \\ Hospitalier \\ Pitié-Salpêtrière, 47 \\ Boulevard de \\ l'Hôpital, 75651 Paris \\ Cedex 13, France \\ J-P Harpey}

Hôpital des Enfants,

Genève, Switzerland

C-A Haenggeli

Correspondence to:

Dr Guicheney.

Received 12 June 1997 Revised version accepted for publication 5 September 1997

\section{Patients, material, and methods}

PATIENTS

In the present study, mutation analysis or prenatal diagnosis was carried out on 14 families (nine consanguineous and five nonconsanguineous) with at least one affected child with a clinicopathological diagnosis of CMD, according to the criteria of the International Consortium on Congenital Muscular Dystrophy. ${ }^{27}$ These families originated from various countries: France $(490,1272,1672$, $2656, \mathrm{BE})$, Italy $(4835,4836, \mathrm{SI}, \mathrm{LI})$, Turkey (1663, 1830), Israel (IF), Belgium (BU), and Morocco (2324). Some of them have been referred to us for prenatal diagnosis. All families gave informed consent before inclusion in this study. A muscle biopsy was performed on one affected child from each family and studied by immunohistochemistry, using an antibody against the $\mathrm{C}$ terminal part of the globular $\mathrm{G}$ domain of the human laminin $\alpha 2$ chain (Chemicon), as previously reported. ${ }^{5}$ Complete deficiency of the laminin $\alpha 2$ chain was observed in patients in 13 families, whereas partial deficiency was shown in one family (1830).

MICROSATELLITE TYPING

D6S407 and D6S1620 microsatellite markers were provided by Généthon human genetic linkage maps. ${ }^{28}$ PCR amplifications were performed on $40 \mathrm{ng}$ genomic DNA, as previously described. ${ }^{29}$

\section{SEQUENCING OF INTRONS AND PCR-SSCP}

ANALYSIS

Sequencing of all 64 exons and their immediate intronic boundaries (30 bp) has previously been reported. ${ }^{26}$ Further sequencing of the introns was carried out directly on our previously purified $\lambda$ clones or subcloned restriction fragments using exon specific oligonucleotide primers as well as the AmpliCycle kit (Perkin-Elmer). Oligonucleotide primers were designed to amplify each LAMA2 exon, based on the intronic sequences using the OLIGO 4.0 program. The primers were chosen so that at least 30 to $50 \mathrm{bp}$ of flanking intron sequences were readable. Amplifications from genomic DNA were performed using the PCR "touchdown" method. ${ }^{30}$ The primer pairs and the initial and final annealing temperatures are given in table 1 , with decreasing of the annealing temperature by $1^{\circ} \mathrm{C}$ after each two cycles and with 30 cycles at lower temperature. At each cycle, denaturation was performed at $94^{\circ} \mathrm{C}$ for 40 seconds and extension at $72^{\circ} \mathrm{C}$ for one minute. Final extension was at $72^{\circ} \mathrm{C}$ for 2.5 minutes. For SSCP analysis, PCR products were denatured for two minutes at $95^{\circ} \mathrm{C}$ after dilution $(1: 4)$ in $10 \%$ saccharose buffer, according to Maruya $e t a{ }^{11}$ with minor modifications, kept in ice, loaded onto $10 \%$ polyacrylamide (37.5:1) minigels, then run at $8 \mathrm{~mA}$ (per gel) at $7^{\circ} \mathrm{C}$ and $20^{\circ} \mathrm{C}$ in a Hoeffer apparatus. The bands were visualised after silver staining of the gels (Biorad). All abnormal conformers were sequenced. When polymorphisms were determined, allele frequencies were estimated by the analysis of 200 normal chromosomes from unrelated subjects.

DIRECT SEQUENCING OF THE PCR PRODUCTS

PCR fragments were centrifuged through a Centricon 100 membrane (Amicon) and sequenced with a $T a q$ cycle sequencing kit (Applied Biosystems) using fluorescent dideoxynucleotides and one of the PCR primers. Reaction products were run on an automated DNA sequencer (Applied Biosystems). All sequences were determined on both strands.

\section{Results}

DETERMINATION OF EXON FLANKING INTRON SEQUENCES AND DESIGN OF PRIMER PAIRS FOR MUTATION DETECTION

Subcloned restriction fragments of genomic $\lambda$ phage clones containing the 64 exons were sequenced using cycle sequencing. At least 50 bp of intron sequences flanking each exon were determined to enable PCR amplification and sequencing of intron sequences likely to be essential for the splicing of the primary transcript. These sequences might be altered in some cases of CMD.

The intron sequences were used to design oligonucleotide primers (table 1) for PCR amplification of the exon regions of the LAMA2 gene. This gene contains exons with sizes varying between 6 and 270 bp. ${ }^{26}$ Sixtythree primer pairs allowed a direct PCR amplification of an exon with the exon/intron boundaries. For exon 5, two overlapping primer pairs were designed. The sizes of the PCR products ranged between 129 and 345 $\mathrm{bp}$, allowing SSCP analysis and direct sequencing.

\section{IDENTIFICATION OF MUTATIONS IN THE LAMA2} GENE

Eight new mutations were identified in LAMA2 associated with MD CMD in nine families (table 2). M1 is a 2 bp deletion at position 1539 in exon 10, 1539delGT, in a French non-consanguineous family (1272). This deletion resulted in the formation of a stop codon (T[GT]AG $\rightarrow$ TAG) in the domain $\mathrm{V}$ that should produce a truncated protein of 496 residues. M2 is also a 2 bp deletion at position 2098 in exon 13, 2098delAG, resulting in a frameshift and a premature termination within 20 amino acid residues in domain $\mathrm{IVb}$. This deletion was identified in three French non-consanguineous families $(490,1272$, 1672) (figs 1 and 2). $M 3$ is a $C$ to $A$ transversion at position 2950 in exon 20 changing a cysteine codon to a stop codon (TGC to TGA) in domain IIIb. This nonsense mutation, Cys967stop, was identified in two nonconsanguineous families originating from Italy (LI, 4835) (figs 1 and 2). M4 is another nonsense mutation in exon 20 at position 3011 , a $\mathrm{C}$ to $\mathrm{T}$ transition changing a glutamine codon to a stop codon (CAA to TAA). This mutation, Gln988stop, was identified in a consanguineous Italian family (4836). M5 is a $1 \mathrm{bp}$ deletion at position 3171 in exon 21, 3171 delG, resulting in a frameshift and a premature stop codon within 33 amino acid 
residues in domain IIIb. This deletion was identified in a consanguineous Turkish family (1663). M6 is a $\mathrm{C}$ to $\mathrm{A}$ transversion at position 4687 in exon 31 , changing a cysteine residue to a stop codon (TGC to TGA). This nonsense mutation in domain IIIa, Cys1546stop, was identified in a consanguineous Italian family (SI). M7 is a $\mathrm{G}$ to $A$ transition at position $6916+1$ of the consensus donor splice site of exon 47 in the DNA of the affected child of family 1672. It is the second mutation transmitted by the father. The mutation occurred in the carboxy terminal G globular domain and its exact effect at the protein level is not known. M8 is a $1 \mathrm{bp}$ deletion at position 8314 in exon 58, 8314delA, in a French consanguineous family (2656), resulting in a frameshift and a premature stop codon within five amino acids in the carboxy terminal $G$ globular domain. The six first mutations should result in truncated proteins lacking domains I and II of the long arm of the laminin $\alpha 2$ chain which normally forms a coil with the carboxyl termini of the $\beta 1$ or $\beta 2$ and $\gamma$ chains. The M7 and M8 mutations occurred in the carboxy terminal G globular domain. M8 should result in the truncation of the two last $G$ repeat domains against which the commercial antibody is raised. The temperatures at which these mutations can be detected by SSCP, as well as the modifications of restriction site they induce, are given in table 2 .

Table 1 Oligonucleotide primers and conditions for PCR amplification of LAMA2 exons

\begin{tabular}{|c|c|c|c|c|c|c|c|c|}
\hline Exon & $\begin{array}{l}\text { Position } \\
\text { on } \\
\text { cDNA }\end{array}$ & $\begin{array}{l}\text { Exon } \\
\text { size } \\
\text { (bp) }\end{array}$ & $\begin{array}{l}\text { Location } \\
\text { upstream } \\
\text { from exon }\end{array}$ & Forward primer sequence $\left(5^{\prime}-3^{\prime}\right)$ & Reverse primer sequence ( $\left.5^{\prime}-3^{\prime}\right)$ & $\begin{array}{l}\text { Location } \\
\text { downstream } \\
\text { from exon }\end{array}$ & $\begin{array}{l}P C R \\
\text { product } \\
\text { size }\end{array}$ & $P C R$ conditions \\
\hline 1 & 50 & 112 & -109 & ССТСTTCССCAGCAGCTG & CCAAGCCCATGCCTCGAC & 6 & 244 & $53^{\circ} \mathrm{C}$ \\
\hline 2 & 162 & 171 & -25 & САCСТTCATTTGTCCATC & GCCACACACCTACACACT & 12 & 225 & $\mathrm{TD} 55-50^{\circ} \mathrm{C}$ \\
\hline 3 & 333 & 113 & -24 & CATATGATGCTGCTAACT & CCACAAACCACTAACTAA & 60 & 214 & $\mathrm{TD} 45-40^{\circ} \mathrm{C}$ \\
\hline 4 & 446 & 243 & -22 & TGTTGTTGTTATACTTCCCT & TATCAAATGTGCTTAAATGG & 19 & 306 & $\mathrm{TD} 55-50^{\circ} \mathrm{C}$ \\
\hline 5 & 689 & 270 & -103 & TGGGAGAATGGGAAGTTA & GCAAACATCATCAAGTCAG & Exonic & 240 & $\mathrm{TD} 55-50^{\circ} \mathrm{C}$ \\
\hline 6 & 959 & 118 & -59 & GCTTCCTTTATGGTTCTA & ATGACGATATTTTGTTGG & 17 & 211 & $\mathrm{TD} 45-40^{\circ} \mathrm{C}$ \\
\hline 7 & 1077 & 179 & -54 & TAAATGTATCTGAAATCAAATT & GTTCAACTGTTTACAGAAGC & 88 & 340 & $\mathrm{TD} 55-50^{\circ} \mathrm{C}$ \\
\hline 8 & 1256 & 100 & -43 & GTTTCTATTCACTTCGTT & AATCATATTTGGCTTTTA & 45 & 205 & $\mathrm{TD} 44-39^{\circ} \mathrm{C}$ \\
\hline 9 & 1356 & 161 & -40 & TTGTTTTAGAAATGTTGA & TTACTGGAATAAACAATG & 4 & 222 & $\mathrm{TD} 44-39^{\circ} \mathrm{C}$ \\
\hline 10 & 1517 & 141 & -56 & CGCAGCTCATAATGTTGA & GCAGCAAACAGAACCAAA & 15 & 229 & $\mathrm{TD} 50-45^{\circ} \mathrm{C}$ \\
\hline 11 & 1658 & 174 & -57 & AAAAGCTGCTGATAGATA & TCAGTTAAAGCAGAATAG & 23 & 271 & TD45- $40^{\circ} \mathrm{C}$ \\
\hline 12 & 1832 & 102 & -50 & TGATTTAATAGCCCATCT & ACATCAGGAAGTAACACG & 26 & 195 & $\mathrm{TD} 45-40^{\circ} \mathrm{C}$ \\
\hline 13 & 1934 & 212 & -47 & СТСTTTTCAGTTTTACTC & CAAAGTAAATGTGTGAAC & 27 & 303 & $\mathrm{TD} 44-39^{\circ} \mathrm{C}$ \\
\hline 14 & 2146 & 112 & -34 & АCTTATTCACCATCTCTT & AAGCACTAAGGATACATT & 14 & 177 & $\mathrm{TD} 50-45^{\circ} \mathrm{C}$ \\
\hline 15 & 2258 & 114 & -33 & CCAAGACTGACTAAAGCC & CCAGGGTAGTAGCTGAAT & 65 & 229 & $\mathrm{TD} 50-45^{\circ} \mathrm{C}$ \\
\hline 16 & 2372 & 128 & -49 & TGATCCCTGACACCAAAA & GAGCTTATTCATGGGGTA & 15 & 209 & $\mathrm{TD} 50-45^{\circ} \mathrm{C}$ \\
\hline 17 & 2500 & 87 & -54 & CTTTGTGTATGTCCTTCT & AATCATTTTGCAAGACAG & 17 & 175 & $\mathrm{TD} 45-40^{\circ} \mathrm{C}$ \\
\hline 18 & 2587 & 212 & -65 & AATATCTAAACATTGCCC & ACATCAATTCTGTCAGGG & 23 & 317 & $\mathrm{TD} 45-40^{\circ} \mathrm{C}$ \\
\hline 19 & 2799 & 107 & -27 & TGATCACAGGTCTCTCTT & TTATGGGTCAGCCTCTAC & 8 & 159 & $\mathrm{TD} 50-45^{\circ} \mathrm{C}$ \\
\hline 20 & 2906 & 181 & -52 & ACTTCGAGTTAACTGATT & ATGTAGGACTTAAGTCAT & 12 & 262 & $\mathrm{TD} 44-39^{\circ} \mathrm{C}$ \\
\hline 21 & 3087 & 137 & -45 & TTТСТАТTTTТССССТТСТTTG & TATCAATGAGCAAAAAAGTGGT & 9 & 212 & $\mathrm{TD} 55-50^{\circ} \mathrm{C}$ \\
\hline 22 & 3224 & 237 & -38 & AAAGTTGTTAATGGTTGC & GAAACAGAATTGAGGGAG & 33 & 325 & $\mathrm{TD} 44-39^{\circ} \mathrm{C}$ \\
\hline 23 & 3461 & 144 & -79 & CTCCCGTTATGCATTCTC & GGCTCAGCAGTTCCCTAC & 5 & 245 & TD $50-45^{\circ} \mathrm{C}$ \\
\hline 24 & 3605 & 180 & -77 & CATGCAGTTCGTAACTTA & GATAAATCTCCAAATGGT & 58 & 332 & $\mathrm{TD} 45-40^{\circ} \mathrm{C}$ \\
\hline 25 & 3785 & 189 & -51 & ACCACTTTGGAGACTTTATC & CACCAAACAATGACTAACTT & 4 & 263 & $\mathrm{TD} 55-50^{\circ} \mathrm{C}$ \\
\hline 26 & 3974 & 134 & -40 & CATTCAGTTTTGTCATAG & AAAATAAGAGCTTGAATA & 19 & 210 & $\mathrm{TD} 44-39^{\circ} \mathrm{C}$ \\
\hline 27 & 4108 & 118 & -27 & ATCTAAGTACATTCTCGC & CAGGTTAGTAGGAGGTAG & 6 & 168 & TD $50-45^{\circ} \mathrm{C}$ \\
\hline 28 & 4226 & 135 & -85 & TGTCTTTGCAGCCACTGA & TTCAAGGAAGGCTCAGAG & 7 & 244 & $\mathrm{TD} 50-45^{\circ} \mathrm{C}$ \\
\hline 29 & 4361 & 125 & -29 & АСАAАCТTСТТСТСССТТ & GTTTCTGATTGGGAAATA & 23 & 194 & TD $50-45^{\circ} \mathrm{C}$ \\
\hline 30 & 4486 & 87 & -23 & САATCCTTTTCTTTCTGA & TGTGACCCTTTACCATAT & 46 & 173 & TD $45-40^{\circ} \mathrm{C}$ \\
\hline 31 & 4573 & 194 & -55 & TGTGGAGACATGACTTGC & CAGCAAAGCAGTATACGT & 3 & 269 & $\mathrm{TD} 55-50^{\circ} \mathrm{C}$ \\
\hline 32 & 4767 & 143 & -54 & TCTGCCTGGGATGTTTAG & CTGCCCTGCTTGTGACTG & 12 & 226 & TD50-45 ${ }^{\circ} \mathrm{C}$ \\
\hline 33 & 4910 & 99 & -26 & ATGTTTATGGGATGGAAT & TAGGAAGAAGGTGATTTG & 81 & 223 & $\mathrm{TD} 55-50^{\circ} \mathrm{C}$ \\
\hline 34 & 5009 & 112 & -25 & GTGTTTCCCGAATTTGGT & ATGATGATTAAATGTGAT & 13 & 167 & $\mathrm{TD} 55-50^{\circ} \mathrm{C}$ \\
\hline 35 & 5121 & 163 & -47 & TGGCATGTTTGTTTACTA & CTGGAAATCTCAGTTTGT & 32 & 259 & TD $50-45^{\circ} \mathrm{C}$ \\
\hline 36 & 5284 & 211 & -58 & ACCCTAAGGCAGTGACAT & CCCAACCTTCTGAGATTA & 26 & 312 & $\mathrm{TD} 44-39^{\circ} \mathrm{C}$ \\
\hline 37 & 5495 & 117 & -24 & TGTCTTGTTCATAATGGT & TCTCTTTTGAGTTTTACC & 11 & 169 & $\mathrm{TD} 44-39^{\circ} \mathrm{C}$ \\
\hline 38 & 5612 & 164 & -25 & AAATGCCСТCTTCTCTAC & CCAAAACAAATGACATAC & 1 & 207 & $\mathrm{TD} 55-50^{\circ} \mathrm{C}$ \\
\hline 39 & 5776 & 139 & -32 & CCCTGCATACTGTTTTTGAAT & GACTTCCATTCCCAGCACAT & 18 & 208 & $\mathrm{TD} 55-50^{\circ} \mathrm{C}$ \\
\hline 40 & 5915 & 103 & -21 & CATTTGTTTTTCTGTCCAC & TCCAATAGTGTGATAGAA & 60 & 201 & $\mathrm{TD} 55-50^{\circ} \mathrm{C}$ \\
\hline 41 & 6018 & 117 & -52 & GCTGAGGGATGATAAAAC & GTTGGTAGTGCCTGAATG & 6 & 192 & $\mathrm{TD} 55-50^{\circ} \mathrm{C}$ \\
\hline 42 & 6135 & 183 & -54 & GCCACTAACTCCACACCC & ACACAATGAAAAAGGAGA & 8 & 262 & $\mathrm{TD} 55-50^{\circ} \mathrm{C}$ \\
\hline 43 & 6318 & 6 & -31 & TTTGTTTTGCTTCCATGTGA & TTCCTTTTACGCATCTACC & 143 & 197 & $\mathrm{TD} 55-50^{\circ} \mathrm{C}$ \\
\hline 44 & 6324 & 155 & -32 & ATATACATGCACACTAAT & CAGTTCTGATATGACGAT & 14 & 218 & TD45- $40^{\circ} \mathrm{C}$ \\
\hline 45 & 6479 & 144 & -51 & CAAACTTTCTGAGAGATT & AGCAGCCTAATGAAAAGT & 17 & 229 & $\mathrm{TD} 50-45^{\circ} \mathrm{C}$ \\
\hline 46 & 6623 & 134 & -34 & TGATATCTCTTGTTTTTG & AATCTTTATTAAGTTGGT & 4 & 189 & $\mathrm{TD} 44-39^{\circ} \mathrm{C}$ \\
\hline 47 & 6757 & 160 & -30 & ТССССТТСАСТTCAACAC & ACAGGAGGAGGATGAACA & 7 & 214 & TD $50-45^{\circ} \mathrm{C}$ \\
\hline 48 & 6917 & 125 & -21 & TAACGGTATTTCTTTCTG & ACCCTGGGAGAGTTCTCA & 12 & 175 & TD $50-45^{\circ} \mathrm{C}$ \\
\hline 49 & 7042 & 163 & -52 & TGACAGACCGAATAGATA & CACGGAAACTCTGCTATG & 15 & 247 & $\mathrm{TD} 44-39^{\circ} \mathrm{C}$ \\
\hline 50 & 7205 & 145 & -29 & CCACTGGGGTATGTTTAC & GGCCTATATTGCATTATT & 16 & 207 & TD $44-39^{\circ} \mathrm{C}$ \\
\hline 51 & 7350 & 139 & -52 & ATGTGGTTGATATTGCTC & AACTTAATCCTTAGCTTT & 20 & 228 & $\mathrm{TD} 44-39^{\circ} \mathrm{C}$ \\
\hline 52 & 7489 & 12 & -21 & TTCСTCTTTCCCGTTATCT & TGGTGTTGCTCTGCTTCTG & 78 & 129 & $\mathrm{TD} 55-50^{\circ} \mathrm{C}$ \\
\hline 53 & 7501 & 121 & -33 & ATTGCTTTTGCTTTTCAT & AGCAGCCACACTAAGTAA & 50 & 221 & TD $50-45^{\circ} \mathrm{C}$ \\
\hline 54 & 7622 & 177 & -29 & TGTCTACTCTTCCTTTTCCT & TGCATTATCAGCTAGGTGTG & 7 & 234 & $\mathrm{TD} 55-50^{\circ} \mathrm{C}$ \\
\hline 55 & 7799 & $149^{\star}$ & -60 & CTAAAGCTAAGCCATAAA & GGAAGTTCACCTGAGTTA & 31 & 256 & TD45-40 ${ }^{\circ} \mathrm{C}$ \\
\hline 56 & 7947 & $177^{\star}$ & -51 & TGTATZGGAATCAGATGTG & GTAGTAGTAATGAGGAGA & 10 & 255 & $\mathrm{TD} 45-40^{\circ} \mathrm{C}$ \\
\hline 57 & 8125 & 169 & -27 & AAAATC TTATTTATTACA & TCССТTCTGAAATGACTC & 51 & 264 & $\mathrm{TD} 44-39^{\circ} \mathrm{C}$ \\
\hline 58 & 8294 & 113 & -71 & TTAGACAGCATCATTACC & TCTTCATTTATCGGTTCT & 28 & 229 & TD53-48 ${ }^{\circ} \mathrm{C}$ \\
\hline 59 & 8407 & 190 & -70 & GATACCGCTCTAT TTTAG & GTAATCCCTTAGGGTACT & 21 & 298 & $\mathrm{TD} 45-40^{\circ} \mathrm{C}$ \\
\hline 60 & 8597 & 156 & -57 & TCTGCATATGTGAAATTT & TCAATAAATGAATCAGCC & 38 & 268 & $\mathrm{TD} 45-40^{\circ} \mathrm{C}$ \\
\hline 61 & 8753 & 154 & -86 & TACACACATAGAGCACCC & TGGATCTAGCAAGAAGTT & 52 & 309 & TD44-39 ${ }^{\circ} \mathrm{C}$ \\
\hline 62 & 8907 & 131 & -40 & АТССТСТАAТCCAAAATA & ATCTACACATCAACAATA & 41 & 229 & TD44-39 ${ }^{\circ} \mathrm{C}$ \\
\hline 63 & 9038 & 223 & -66 & TGTGTGAACCATCATGAT & GAAATTGTTGCTGGGGTA & 13 & 319 & $\mathrm{TD} 50-45^{\circ} \mathrm{C}$ \\
\hline 64 & 9261 & 269 & -24 & GCCCTCTTGCATTGCCTT & TCTGGAGTGTCAATTAGCA & 23 & 334 & $\mathrm{TD} 55-50^{\circ} \mathrm{C}$ \\
\hline
\end{tabular}


Table 2 New LAMA2 mutations causing laminin a2 chain deficiency

\begin{tabular}{|c|c|c|c|c|c|c|c|}
\hline & Mutations & Exons & Domains & $\begin{array}{l}\text { Sequence } \\
\text { variation }\end{array}$ & $\begin{array}{l}\text { Size of the } \\
\text { putative } \\
\text { proteins }\end{array}$ & $S S C P$ & Restriction site \\
\hline $\begin{array}{l}\text { M1 } \\
\text { M2 } \\
\text { M3 } \\
\text { M4 } \\
\text { M5 } \\
\text { M6 } \\
\text { M7 } \\
\text { M8 }\end{array}$ & $\begin{array}{l}\text { Cys497stop } \\
\text { 2098delAG } \\
\text { Cys967stop } \\
\text { Gin988stop } \\
\text { 3171delG } \\
\text { Cys1546stop } \\
\text { 6916+1 G } \rightarrow \text { A } \\
\text { 8314delA }\end{array}$ & $\begin{array}{l}10 \\
13 \\
20 \\
20 \\
21 \\
31 \\
47 \\
58\end{array}$ & $\begin{array}{l}\text { V } \\
\text { IVb } \\
\text { IIIb } \\
\text { IIIb } \\
\text { IIIb } \\
\text { IIIa } \\
\text { G } \\
\text { G }\end{array}$ & $\begin{array}{l}\text { 1539delGT } \\
\text { 2098delAG } \\
\text { 2950 C } \rightarrow \mathrm{A} \\
3011 \mathrm{C} \rightarrow \mathrm{T} \\
3171 \mathrm{delG} \\
4687 \mathrm{C} \rightarrow \mathrm{A} \\
6916+1 \mathrm{G} \rightarrow \mathrm{A} \\
8314 \text { delA }\end{array}$ & $\begin{array}{l}496 \\
702 \\
966 \\
987 \\
1073 \\
1545 \\
\text { Unknown } \\
2759\end{array}$ & $\begin{array}{l}7^{\circ} \mathrm{C} \\
7 \text { and } 20^{\circ} \mathrm{C} \\
7 \text { and } 20^{\circ} \mathrm{C} \\
7^{\circ} \mathrm{C} \\
20^{\circ} \mathrm{C} \\
20^{\circ} \mathrm{C} \\
7^{\circ} \mathrm{C} \\
7 \text { and } 20^{\circ} \mathrm{C}\end{array}$ & $\begin{array}{l}\text { New SpeI and MaeI } \\
\text { No change } \\
\text { No change } \\
\text { Loss NlaIV and BanI } \\
\text { No change } \\
\text { Loss PlnI and BsaAI } \\
\text { No change } \\
\text { New TaqI }\end{array}$ \\
\hline
\end{tabular}

IDENTIFICATION OF LAMA2 POLYMORPHISMS

We detected 13 polymorphisms in nine exons (table 3). Eight were silent polymorphisms and five induced amino acid changes in exons 12, 37,55 , and 56 . Several polymorphisms induce a loss or creation of a restriction site and all can be detected by SSCP analysis at $7^{\circ} \mathrm{C}$ or $20^{\circ} \mathrm{C}$, or at both temperatures, as mentioned in table 3. The frequencies of the less frequent alleles were estimated for most of the polymorphisms (table 3 ). The $A \rightarrow G$ polymorphism at position 5551 in exon 37 is the most informative with a frequency of $38 \%$ for allele $G$ and $62 \%$ for allele $\mathrm{A}$. Several rare variants were identified in 2 to $5 \%$ of the chromosomes which were analysed. In exon 55, the presence of at least three polymorphisms accounts for the various SSCP patterns observed, each corresponding to a different allelic combination. The respective frequencies of these polymorphisms have not been determined. We identified three additional polymorphisms in introns 4,30 , and 52 in the PCR products corresponding to exons 5 , 30 , and 52 , respectively.

APPLICATION TO RESEARCH OF FOUNDER EFFECTS SSCP analysis of exon 13 and exon 20 PCR products showed the same deletion, 2098delAG, in three French families and the same nonsense mutation, Cys967stop, in two families originating from Italy (fig 1). These five families were non-consanguineous, suggesting that two different mutations cause the disease. We identified the two mutations in

A
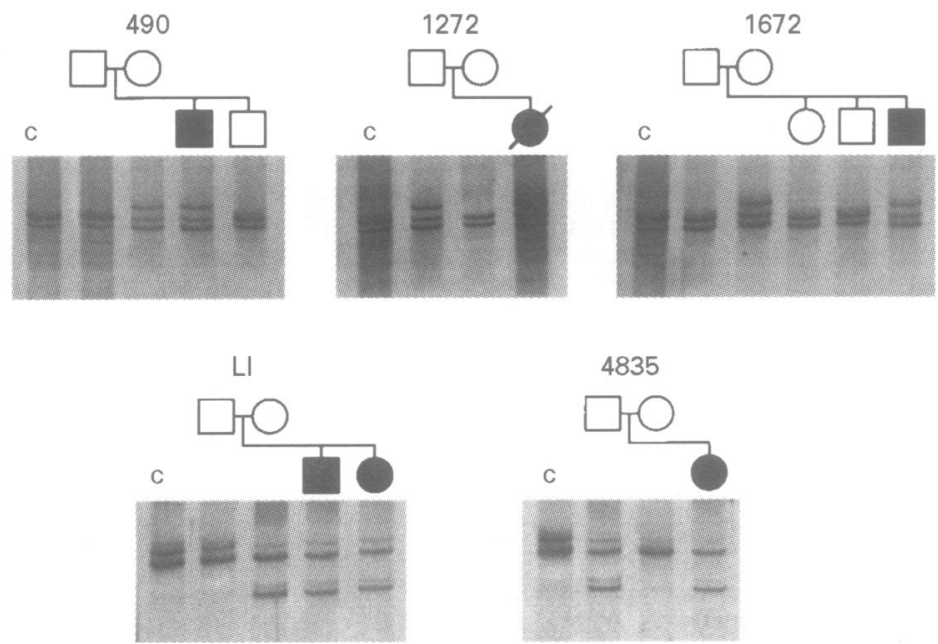

Figure 1 SSCP analysis of the three French families with a 2098delAG mutation (A) and the two Italian families with a Cys967stop mutation (B). Abnormal conformers were detected for the probands compared to the control $(C)$. In each family, the proband and one of his parents was heterozygous for the mutation in agreement with the haplotypes shown in fig 2. only two families, family 1272 (2098delAG and 1539delGT) and family 1672 (2098delAG and $6916+1 \mathrm{G} \rightarrow \mathrm{A})$. Analysis of the microsatellite markers D6S407 and D6S1620, which are the closest so far known to the LAMA2 locus, did not show whether the mutations 2098delAG and Cys967stop were independent mutational events or related ones (fig 2 ).

By the study of intragenic polymorphisms, we were able to show that the three French families shared the same haplotype associated with the 2098delAG mutation, suggesting that these families probably have a remote degree of consanguinity (fig 3 ). The $\mathrm{G}$ at position 2848 , which is the less common allele, is associated with the 2098delAG deletion in these families.

In the Italian families a rare variant of exon $37, A$ at position 5579 , was found associated with the Cys967stop mutation. The two families shared the same haplotype, which also suggests a founder effect (fig 2).

APPLICATION TO PRENATAL DIAGNOSIS

Six families were referred to us for prenatal diagnosis (fig 3 ). In addition to the two microsatellites bordering the LAMA2 locus, D6S407 and D6S1620, we analysed at least exons 12, 19,37 , and 42 in each family for polymorphism detection. As shown in fig 3, by haplotyping the microsatellites and polymorphisms, we could determine the two at risk haplotypes in each family and their presence in the DNA samples from trophoblastic biopsies (fig 3). The polymorphisms of exons 12, 19, and 42, 1905 $\mathrm{G} \rightarrow \mathrm{A}, 2848 \mathrm{~A} \rightarrow \mathrm{G}$, and $6286 \mathrm{G} \rightarrow \mathrm{A}$, were informative in two, two, and one of the six families, respectively, whereas the polymorphism of exon $37,5551 \mathrm{~A} \rightarrow \mathrm{G}$, was informative in all the six families. For the cases described here, all the fetuses have received only one or no disease haplotype, without any evidence of recombination. In two cases, study of the mutations already identified (family 1272, see above, and family 2324, 2418delC in exon $16^{23}$ ) have strengthened the conclusions of the haplotype analysis.

\section{Discussion}

The laminin $\alpha 2$ chain is a large protein of the extracellular matrix. The gene, LAMA2, contains 64 exons, 62 with sizes varying between 87 and $270 \mathrm{bp}$ and two unusually small ones, exon 43 and exon 52, with 6 and 12 base pairs, respectively. ${ }^{26}$ Further sequencing of exon flanking intron regions allowed PCR amplification of sufficiently long intron sequences to ensure sequencing and mutation detection of 
D6S407 $1539 \Delta$ GT 1905 G-A $2098 \triangle A G$ 2848 A-G 5551 A-G D6S1620

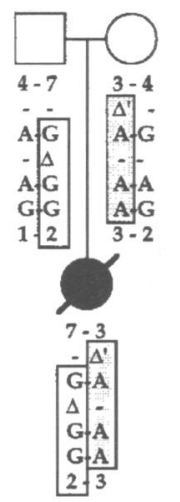

LI

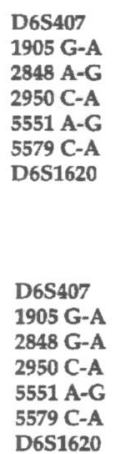

D6S407 1905 G-A $2098 \triangle A G$ 2848 A-G 5551 A-G
D6S1620

D6S407 1905 G-A $2098 \triangle A G$ 2848 A-G 5551 A-G D6S1620

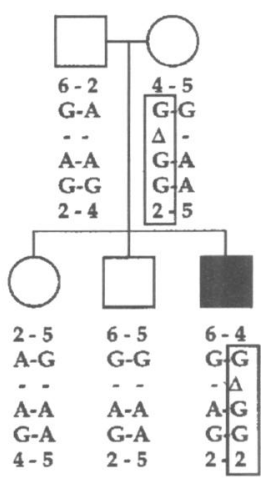

Figure 2 Search for founder effects with intragenic polymorphisms. The haplotypes associated with the mutation 2098 delAG found in French families $(490,1272,1672)$ are in white boxes; those corresponding to the mutation Cys967stop in two Italian families $(L I, 4835)$ are shown in grey boxes.

the splice consensus sequences. Optimal PCR conditions were determined for each exon region of the LAMA2 gene. By PCR-SSCP and direct sequencing, we identified 14 different mutations, including the eight new ones of this report, in CMD patients with complete merosin deficiency. ${ }^{21}$ all these mutations were 1 or $2 \mathrm{bp}$ deletions, nonsense, or splice mutations, leading to truncated proteins and absence of immunoreactivity with antibody directed against the C-terminal part of the protein. Three additional mutations have been reported by other groups, including a 5 bp deletion $^{20}{ }^{22}$ and a large deletion..$^{22}$ Systematic screening, exon by exon, of such a large gene is expensive and time consuming. Nevertheless, such an approach cannot be avoided to detect missense mutations, such as the Cys996Arg, causing CMD with partial merosin deficiency. ${ }^{11}$ To detect mutations causing CMD with a complete deficiency, the protein truncation test (PTT) would be a more appropriate approach, ${ }^{32}{ }^{33}$ especially since we have only identified 60 to $70 \%$ of the mutations by PCR-SSCP mutation screening.

By analysing the various LAMA2 exons, we identified 16 polymorphisms, three in introns and 13 in exons. Most of them are silent polymorphisms, but five induce an amino acid change without any known physiological consequences. Four of these polymorphisms, $1905 \mathrm{G} \rightarrow \mathrm{A}, 2848 \mathrm{~A} \rightarrow \mathrm{G}, 5551 \mathrm{~A} \rightarrow \mathrm{G}$, and 6286 $\mathrm{G} \rightarrow \mathrm{A}$, in exons $12,19,37$, and 42 , respectively, have an allele frequency above $16 \%$ and can be useful as polymorphic markers, especially for prenatal diagnosis. The $A$ to $G$ polymorphism

Table 3 LAMA2 polymorphisms

\begin{tabular}{|c|c|c|c|c|c|}
\hline Exon & Nucleotide & Amino acid & Frequency & Restriction site & SSCP conditions \\
\hline $\begin{array}{l}10 \\
12 \\
12 \\
19 \\
33 \\
37 \\
37 \\
42 \\
54 \\
55 \\
55 \\
55 \\
56\end{array}$ & $\begin{array}{l}1540 \mathrm{~T} \rightarrow \mathrm{C} \\
1847 \mathrm{G} \rightarrow \mathrm{A} \\
1905 \mathrm{G} \rightarrow \mathrm{A} \\
2848 \mathrm{~A} \rightarrow \mathrm{G} \\
5005 \mathrm{C} \rightarrow \mathrm{G} \\
5551 \mathrm{~A} \rightarrow \mathrm{G} \\
5579 \mathrm{C} \rightarrow \mathrm{A} \\
6286 \mathrm{G} \rightarrow \mathrm{A} \\
7669 \mathrm{C} \rightarrow \mathrm{G} \\
7809 \mathrm{~T} \rightarrow \mathrm{C} \\
7879 \mathrm{C} \rightarrow \mathrm{G} \\
7894 \mathrm{G} \rightarrow \mathrm{A} \\
7955 \mathrm{~A} \rightarrow \mathrm{G}\end{array}$ & $\begin{aligned} & 497 \text { TGT(Cys) } \rightarrow \text { TGC(Cys) } \\
& 600 \text { GGA (Gly) } \rightarrow \text { AGA(Arg) } \\
& 619 \text { CGT(Arg) } \rightarrow \text { CAT(His) } \\
& 933 \text { CAA(Gln) } \rightarrow \text { CAG(Gln) } \\
& 1663 \text { ACC(Thr) } \rightarrow \text { ACG(Thr) } \\
& 1834 \text { GAA(Glu) } \rightarrow \text { GAG(Glu) } \\
& 1844 \text { CGT(Arg) } \rightarrow \text { AGT(Ser) } \\
& 2079 \text { ACG(Thr) } \rightarrow \text { ACA(Thr) } \\
& 2540 \text { TCC(Ser) } \rightarrow \text { TCG(Ser) } \\
& 2587 \text { GTA(Val) } \rightarrow \text { GCA(Val) } \\
& 2610 \text { GTC(Val) } \rightarrow \text { GTG(Ala) } \\
& 2615 \text { CCG(Pro) } \rightarrow \text { CCA(Pro) } \\
& 2636 \text { ACA(Thr) } \rightarrow \text { GCA(Ala) }\end{aligned}$ & $\begin{array}{r}2 \% \\
2 \% \\
18 \% \\
24 \% \\
3 \% \\
38 \% \\
2 \% \\
16 \% \\
17 \% \\
\text { ND } \\
\text { ND } \\
\text { ND } \\
6 \%\end{array}$ & $\begin{array}{l}\text { New PstI } \\
\text { Loss } M n l I \\
\text { Loss } M a e I I \\
\text { No change } \\
\text { Loss } E c o R I \\
\text { New } M n l I \\
\text { No change } \\
\text { Loss BsmI } \\
\text { No change } \\
\text { No change } \\
\text { New BclI } \\
\text { Loss Hinf } \\
\text { No change }\end{array}$ & $\begin{array}{l}7^{\circ} \mathrm{C}, 20^{\circ} \mathrm{C} \\
7^{\circ} \mathrm{C} \\
7^{\circ} \mathrm{C} \\
7^{\circ} \mathrm{C}, 20^{\circ} \mathrm{C} \\
7^{\circ} \mathrm{C} \\
7^{\circ} \mathrm{C} \\
7^{\circ} \mathrm{C} \\
20^{\circ} \mathrm{C} \\
7^{\circ} \mathrm{C} \\
20^{\circ} \mathrm{C} \\
20^{\circ} \mathrm{C} \\
20^{\circ} \mathrm{C} \\
7^{\circ} \mathrm{C}\end{array}$ \\
\hline
\end{tabular}

$\mathrm{ND}=$ not determined . 


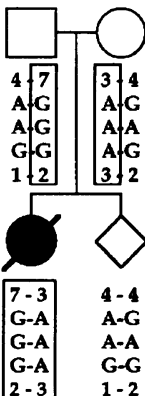

BE

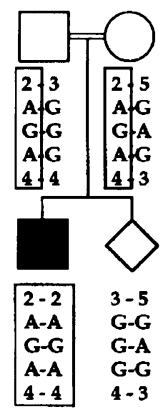

1830

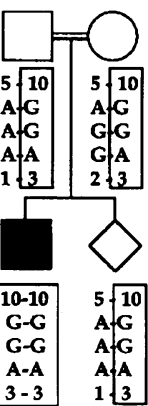

2324
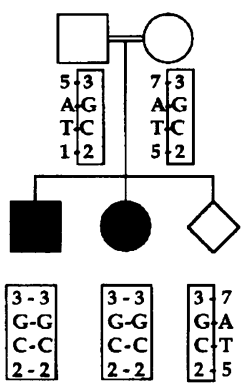

D65407

$1905 \mathrm{G}-\mathrm{A}$

$6551 \mathrm{~A}-\mathrm{G}$

D6S1620

D6S407

$1905 \mathrm{G}-\mathrm{A}$

5551 A-C

D6S1620
列
IF

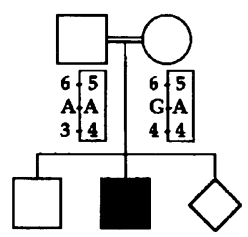

$\begin{array}{lll}5 & 6 \\ A & 6 \\ 4 & 4\end{array}$

D6S1620

D6S407

5551 A-G
D6S1620
D6S407

6285 A-G

6286 G-A

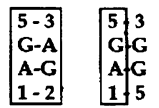

D6S407

D5S1620

6286 G-A

Figure 3 Haplotypes of informative polymorphisms and two microsatellites: application to prenatal diagnosis.

at position 5551 is the most informative one and induces the creation of a new $M n l$ restriction site. It was informative in our experience for the 11 prenatal diagnoses we performed (data not shown). These polymorphisms can be analysed to obtain more information in case of recombination between the two flanking microsatellite markers. Some of them do not induce the creation or the loss of a restriction site but they can all be easily detected by SSCP. The pattern associated with each polymorphism can be established using a reference panel of DNA samples which have been sequenced.

We present here two new mutations in the LAMA2 gene in non-consanguineous families. A 2 bp deletion at position 2098 in exon 13, 2098delAG, which results in the truncation of the laminin $\alpha 2$ chain in domain IVb, was found in three French families. Analysis of intragenic polymorphisms suggests that these three families are related. The nonsense mutation, Cys967stop, in exon 20, which results in the truncation of the laminin $\alpha 2$ chain in domain IIIb, was identified in two families of Italian origin. These two families also probably have a remote degree of consanguinity since a rare polymorphism, adenine at position 1847 , was found linked to the mutation. The two families originate from the south of Italy on the Adriatic coast. Analysis of the various polymorphisms of the gene could be used to identify founder effects in the populations. We previously reported that the rare polymorphism in exon 10 , cytosine at position 1540 , was linked to the Gln1241stop nonsense mutation identified in a family originating from Tunisia. ${ }^{21}$

This study provides valuable methods for determining the molecular defects in LAMA2 causing merosin deficient congenital muscular dystrophy.

This work was supported by the Institut National de la Sante et de la Recherche Médicale, the Association Française contre les Myopathies (AFM, France), and the French Research Ministry (Actions Concertées Coordonnées - Sciences du vivant) as well as the Swedish Medical Research Council. We thank Dr A Urtize M Shobat, Dr N Philip, and Dr J Leroy for referring families, and Dr V Paquis and Dr F Leturcq for DNA extraction.

1 Fardeau M. Congenital myopathies. In: Mastaglia FL, Lord Walton of Detchant, eds. Skeletal muscle pathology. Edinburgh: Churchill Livingstone, 1992:237-81.

2 Banker BQ. The congenital muscular dystrophy. In: Engel AG, Franzini-Amstrong C, eds. Myology. Vol 2. New York: AG, Franzini-Amstrong C, eds.

3 Dubowitz V. 41st ENMC International Workshop on Congenital Muscular Dystrophy, Naarden, The Netherlands. genital Muscular Dystrophy, Naarder
Neuromusc Disord 1996;6:295-306.

4 Pini A, Merlini L, Tomé FMS, Chevallay M, Gobbi G. Merosin-negative congenital muscular dystrophy, occipital epilepsy with periodic spasms and focal cortical dysplasia. Report of three Italian cases in two families. Brain Dev 1996;18:316-22

5 Tomé FMS, Evangelista T, Leclerc A, et al. Congenital muscular dystrophy with merosin deficiency. $C R$ Acad $S c i$ Paris 1994;317:351-7.

6 Minetti C, Bado M, Morreale G, Pedemonte M, Cordone G. Disruption of muscle basal lamina in congenital muscular dystrophy with merosin deficiency. Neurology 1996;46: 1354-8.

7 Osari S, Kobayashi O, Yamashita Y, et al. Basement membrane abnormality in merosin-negative congenital membrane abnormality in merosin-negative congenta

8 Philpot J, Sewry C, Pennock J, Dubowitz V. Clinical phenoPhilpot J, Sewry C, Pennock J, Dubowitz V. Clinical phenotype in congenital muscular dystrophy: correlation with expression of mer.

9 Fardeau M, Tomé FMS, Helbling-Leclerc A, et al. Dystrophie musculaire congénitale avec déficience en mérosine: analyse clinique, histopathologique, immunocytochimique t génétique. Rev Neurol (Paris) 1996;152:11-19.

10 Vainzof M, Marie SKN, Reed UC, et al. Deficiency of merosin (laminin $\mathrm{M}$ or 2 ) in congenital muscular dystrophy associated with cerebral white matter alterations. Neuropediatrics 1995;26:293-7.

11 Nissinen M, Helbling-Leclerc A, Zhang X, et al. Substitution of a conserved cysteine-996 in a cysteine-rich motif of the laminin $\alpha 2$-chain in congenital muscular dystrophy with partial deficiency of the protein. Am $₹$ Hum Genet 1996;58:1177-84

12 Herrmann R, Straub V, Meyer K, Wagner M, Voit T. Congenital muscular dystrophy with laminin $\alpha 2$ deficiency: identification of a new intermediate phenotype and 
correlation of clinical findings to muscle immunohistochemistry. Eur $¥$ Pediatr 1996;155:968-76.

13 Mora M, Moroni I, Uziel G, et al. Mild clinical phenotype in a 12-year-old boy with a partial merosin deficiency and central and peripheral nervous system abnormalities. Neuromusc Disord 1996;6:377-81.

14 Mercuri E, Pennock J, Goodwin F, et al. Sequential study of central and peripheral nervous system involvement in an infant with merosin-deficient congenital muscular dystrophy. Neuromusc Disord 1996;6:425-9.

15 Van der Knapp MS, Smit LME, Barth PG, et al. Magnetic resonance imaging in classification of congenital muscula dystrophies with brain abnormalities. Ann Neurol 1997;42: 50-9.

16 Mercuri E, Muntoni F, Berardinelli A, et al. Somatosensory and visual evoked potentials in congenital muscular dystrophy: correlation with MRI changes and muscle merosin status. Neuropediatrics 1995;26:3-7.

17 Shorer Z, Philpot J, Muntoni F, Sewry C, Dubowitz V. Demyelinating peripheral neuropathy in merosin-deficien congenital muscular dystrophy. F Child Neurol 1995;10: 472-5.

18 Sunada Y, Edgar TS, Lotz BP, Rust RS, Campbell KP. Merosin-negative congenital muscular dystrophy associated with extensive brain abnormalities. Neurology $1995 ; 45$ : 2084-9.

19 Allamand V, Sunada Y, Salih MAM, et al. Mild congenital muscular dystrophy in two patients with an internally

20 Hayashi YK, Ishihara T, Domen K, Hori H, Arahata K. A benign allelic form of laminin $\alpha 2$ chain deficient muscular dystrophy. Lancet 1997;349:1147.

21 Helbling-Leclerc A, Zhang X, Topaloglu H, et al. Mutation in the laminin $\alpha 2$-chain gene (LAMA2) cause merosindeficient congenital muscular dystrophy. Nat Genet 1995 11:216-18.

22 Pegoraro E, Mancias P, Swerdlow SH, et al. Congenital muscular dystrophy with primary laminin $\alpha 2$ (merosin) deficiency presenting as inflammatory myopathy. Ann Neurol 1996;40:782-91.
23 Guicheney P, Vignier N, Helbling-Leclerc A, et al. Genetics of laminin $\alpha 2$ chain (or merosin) deficient congenital musprenatal diagnosis. Neuromusc Disord 1997;7:187-90.

24 Wever UM, Engvall E. Merosin/laminin-2 and muscular dystrophy. Neuromusc Disord 1996;6:409-18.

25 Vuolteenaho $R$, Nissinen $M$, Sainio $K$, et al. Human laminin $M$ chain (merosin): complete primary structure, chromo$M$ chain (merosin): complete primary structure, chromosomal assignment, and expression of the $M$ and $A$

26 Zhang X, Vuolteenaho R, Tryggvason $K$. Structure of the human laminin $\alpha 2$-chain gene $(L A M A 2)$, which is affected in congenital muscular dystrophy. $\mathcal{F}$ Biol Chem 1996;271: 27664-9.

27 Dubowitz V. 22nd ENMC sponsored workshop on congenital muscular dystrophy held in Baarn, The Netherlands, 14-16 May 1993. Neuromusc Disord 1994;4:75-81.

28 Dib C, Fauré S, Fizames C, et al. A comprehensive genetic map of the human genome based on 5264 microsatellites. Nature 1996;380:152-4.

29 Helbling-Leclerc A, Topaloglu H, Tomé FMS, et al. Readjusting the localization of merosin (laminin a2-chain) deficient congenital muscular dystrophy locus on chromosome 6q2. CR Acad Sci Paris 1995;318:1245-52.

30 Don RH, Cox PT, Wainwright BJ, Baker K, Mattick JS. "Touchdown" PCR to circumvent spurious priming during "Touchdown" PCR to circumvent spurious priming

31 gene amplification. Nucleic Acids Res 1991;19:4008. strength single-stranded conformation polymorphism)-a simple method for high resolution allele typing of HLA-DRB1, -DQB1, and -DPB1. Genome Meth 1996;6: 51-7.

32 Roest PAM, Roberts RG, van der Tuijn AC, et al. Protein truncation test (PTT) to rapidly screen the DMD gene for translation terminating mutations. Neuromusc Disord 1993; 3:391-4.

33 Roest PAM, Roberts RG, Sugino S, van Ommen GJB, den Dunnen JT. Protein truncation test (PTT) for rapid detection of translation-terminating mutations. Hum Mol Genet 1993;2:1719-21. 